\title{
Supply chain optimization by means of product packaging reuse: a case study
}

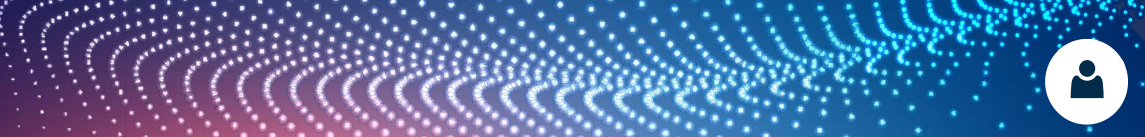

Cecilia.gallvez23@gmail.com

idherrera@utn.edu.ec

christian.diaz02@epn.edu.ec

Martha C. Gálvez Tapia 1, Israel D. Herrera-Granda² and Christian S. Díaz Cajas ${ }^{3}$

${ }^{1}$ Facultad de Ciencias Naturales y Matemáticas, Escuela Superior Politécnica del Litoral, Cam-

pus Gustavo Galindo - km. 30.5 vía perimetral Guayaquil, Ecuador

${ }^{2}$ Facultad de Ingeniería en Ciencias Aplicadas, Universidad Técnica del Norte,

Av. 17 de Julio, 5-21, y Gral. José María Cordova Ibarra, Ecuador

${ }^{3}$ Escuela de Formación de Tecnólogos, Escuela Politécnica Nacional,

Av. Ladrón de Guevara E11-253, Quito, Ecuador

Cecilia.galvez23@gmail.com, idherrera@utn.edu.ec, christian.diaz02@epn.edu.ec

\section{ABSTRACT}

The current work shows the application of reverse logistics in the supply chain of a multinational company wich distributes mass consumption products focused on re-utilization of packaging boxes, and increase of storage capacity and product transportation. Based on the methodologies developed, a logical framework is implemented in a multinational company of consumer products centered on the Out Of The Box, Project Manajement Body of Knowledge and Lean Six Sigma methodologies. A part of this logical framework has been successfully implemented in: Brazil, Mexico, Argentina and Colombia. The execution includes the following stages: identifying which products or stock keeping units in the warehouse can be standardized, designing packaging prototypes of packages or boxes that can be reused from the manufacturers of raw materials until the finished product and that can be used for reuse in packaging of other similar products, quality tests are executed in order to ensure the strength and longevity of the boxes. As a result of its implementation, an increase of financial efficiency was obtained for the company in case, , reducing its logistics costs in comparison with the sales revenues by around $8 \%$, as well as a significant improving of its environmental management .

Keywords: Reverse logistics, Packing boxes, Transportation, Supplier integration, Manufacturing centers, Supply chain. 


\section{Introduction}

Reverse logistics is a subsystem of the Supply Chain (SC) that is poorly exploited in Ecuador and the latin american networks. Within the context we can mention the low integration of suppliers for the efficient management of their supply and distribution networks, this is a consequence of the existing logistics platform, the priority use of unimodal transport, the concentration of road transport, the influence of Customs regulations, the existence of several suppliers with insufficient production capacity scattered in several locations within small territories and the absence of studies on operational productivity initiatives[1], [2], [3], [4], [5].

From academic point of view, at local and regional level there are very few studies similar to the present, being the work published in 2018 by Rodriguez one of them who evidence a successful implementation of the method for packaging management in the $\mathrm{SC}[6]$.

The project complexity was increased since the analyzed company has more than 7000 Stock Keeping Units (SKU), of which $30 \%$ of the share are innovations, it means non-regular sale products. Taking advantage of this information, it is identified which products are susceptible to be included in the project, taking great care of the logistics and packaging selection.

Once it has been established, the design and improvement of the ideal packaging to be used in the SC netwok, for this purpose, it is required to consider several variables such as the percentage of occupation of products in the boxes, the productivity in line of shipments and transportation lines, the density of the warehouse, vehicle occupancy, operating costs, productivity and ergonomics.

The project design is composed of five programs wich are aligned to each strategic partner scope of the value chain as well as to the key processes. All of them are described as follows.

Internal Manufacturing: Products manufactured in the main plants located in Latin America and the Distribution Centers (DC) of each country in which brand Company has presence. 
Manufacturing Centers (CM's): Some places where the company has a product manufacturing flow through toll manufacturing systems.

Raw Material and Component Suppliers: Deliver several materials in a continuous supplying flow of supply, necessary to meet production in own factories and in toll manufacturing systems (contract manufacturing $\mathrm{CM}^{\prime} \mathrm{s}$ ).

Finished product suppliers: Supply continuous and direct DC's with finished products, ready for sale.

Clients: Corresponds to the product flows which are sent from the Distribution Centers of the company to customers.

Based on previous studies and the integration of the key partners described above, the company organizes its business logistics based on the System: Plan, Operate and Control (PAC) [5], [7],[8]. Therefore, it is identified several opportunities to maximize its business, which are mentioned in below lines.

Reuse of wrapping elements, packaging and pallets; Redesign and standardization of packaging or boxes.

Increase of productivity in storage capacity with the optimization of the stacking pattern of each pallet based on the use of the new box.

Transportation Productivity as a consequence of the increase of load capacity using double stack systems, reducing the amount of trips and the implementation of round trips "round trip" that takes advantage of the efficient use of the fleet of trucks in the frecuent routes. For instance, maritime ports to DC's and their returns to the manufacturing centers, They are known as closed transport circuits, which reduce transportation costs due to scale economies. The PAC system is illustrated in Fig. 1.

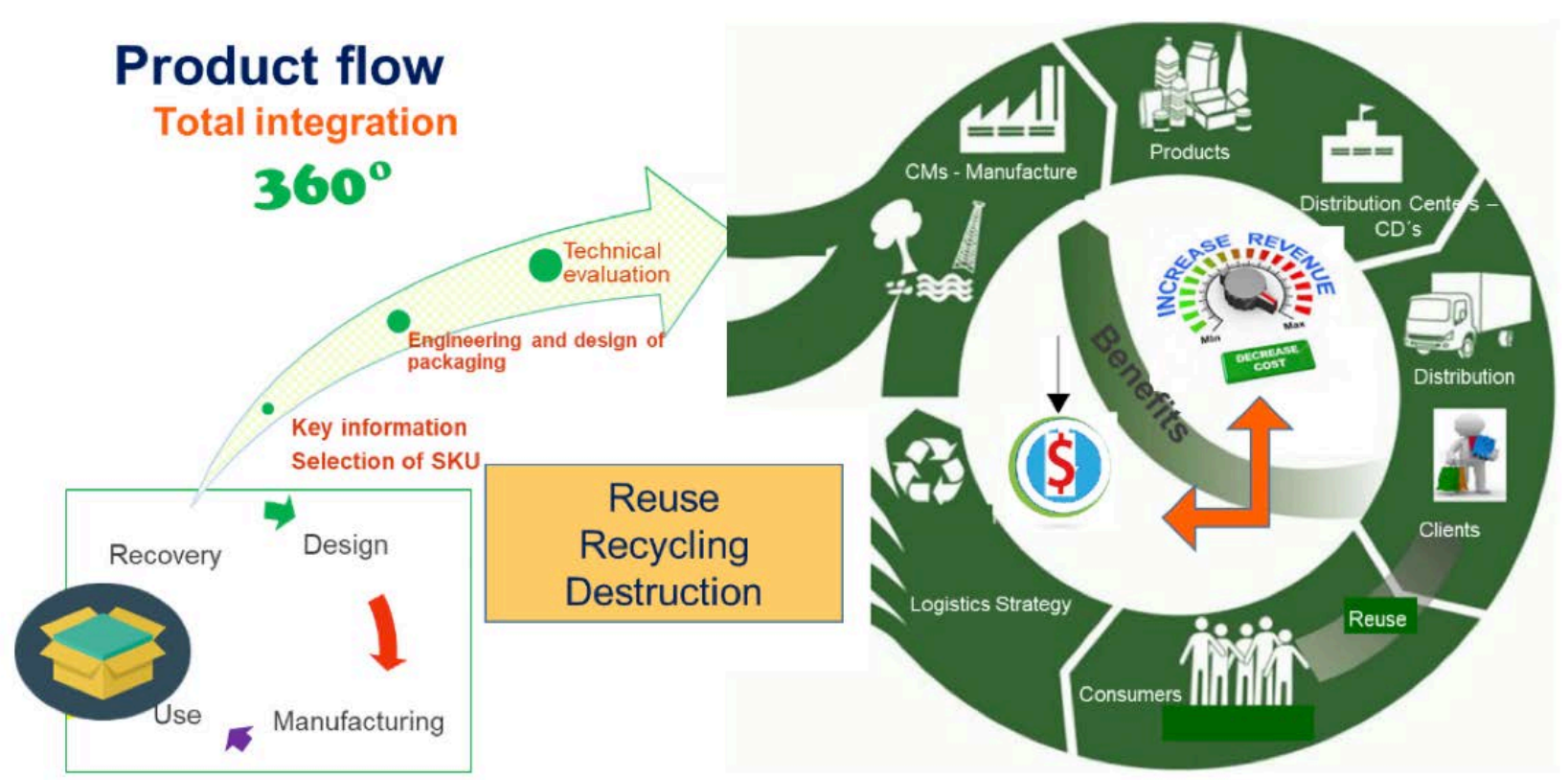

Fig. 1. Strategic business logistics concept-PAC[8] 
The objective of this paper is to show a case study of a company in our region that, based on the proper management of its packaging, reduces its operating costs, which can be replicated in other local companies.

\section{$1 \quad$ Materials and Methods}

The project was designed using key approaches for the development of projects such as: Lean Six Sigma, Project Manajement Body of Knowledge (PMBOK) [9], and Out Of The Box (OTB). It is important to mention that the OTB methodology is suitable for any market and business, where it is possible to realize financial, operational and environmental benefits In terms of design and packaging development, the company was supported by experts in packaging engineering who used specialized software such as Maxload [10] and TOPs [11]. These softwares will be applied only on the standardized boxes through paretto analysis. A summary of the stages of the project is shown in Fig. 2.

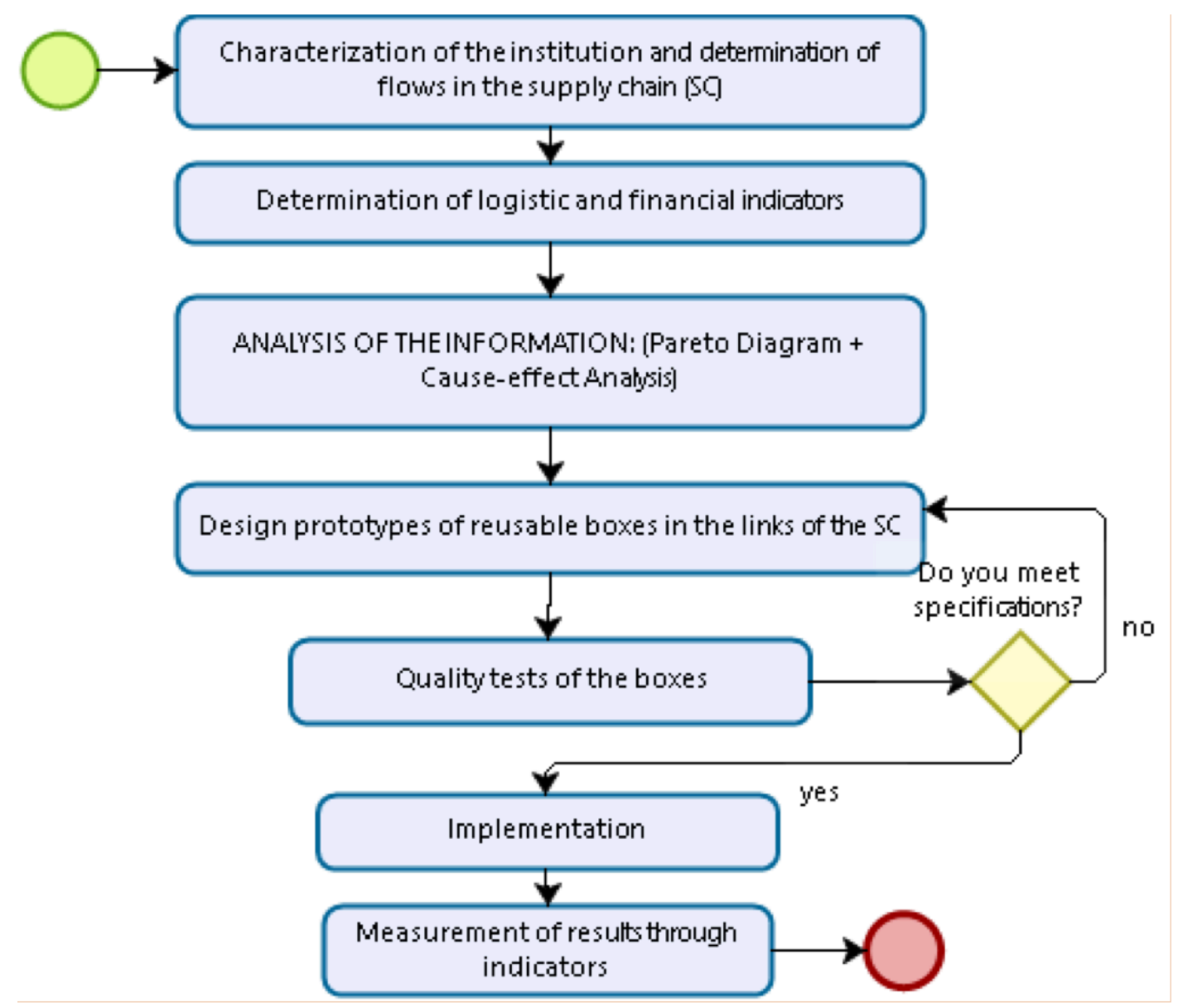

Fig. 2. Stages of the project to optimize the use of packaging.

\subsection{Characterization of the Supply Chain}

The analyzed company is a multinational that produces and distributes mass consumption products with presence in more than 10 countries in Latin America, and moves more than 83.000 tons of cargo with more than 1000 routes and approximately 26.000 transactions will be done in order to connect 5 factories with 11 distribution centers (DC's) which have to supply to around in total 100 delivery points. The present work is focused in the oerations of Colombia, Peru and Ecuador (CPE cluster). At the level of the CPE cluster, around 7000 
SKUs are handled.

Within the characterization of the SC of the mentioned company, the significant entities that interacts have to be defined pursuing the purpose of the improvement of the use of packaging. For this, the Suppliers, Inputs, Process, Outputs, and Customers (SIPOC) table was used, as shown in Table 1.

\begin{tabular}{|c|c|c|c|c|}
\hline Suppliers (S) & Inputs (I) & Process (P) & Output (O) & Clients (C) \\
\hline $\begin{array}{l}\text { - Manufacturing } \\
\text { centers. }\end{array}$ & $\begin{array}{l}\text { Redefinition of } \\
\text { new } \\
\text { manufacturing } \\
\text { packaging } \\
\text { standard. }\end{array}$ & $\begin{array}{l}\text { Management of } \\
\text { boxes and } \\
\text { implementation } \\
\text { of reuse cycles. }\end{array}$ & $\begin{array}{l}\text { - Implementation of } 8 \text { to } \\
10 \text { cases of } \\
\text { manufacturing. }\end{array}$ & $\begin{array}{ll}\text { - } & \text { Clúster } \\
& \text { CPE }\end{array}$ \\
\hline $\begin{array}{l}\text { - Material } \\
\text { suppliers. }\end{array}$ & $\begin{array}{l}\text { Definition of } \\
\text { method of } \\
\text { transporting } \\
\text { product to DC's. }\end{array}$ & $\begin{array}{l}\text { Implementation } \\
\text { of double stack } \\
\text { in trips. }\end{array}$ & $\begin{array}{l}\text { Pallet with maximum } \\
\text { height of } 1.15 \mathrm{~m} \text { and } \\
1.35 \mathrm{~m} \text { maximum weight } \\
\text { 900kg. }\end{array}$ & \\
\hline \multirow{2}{*}{$\begin{array}{l}\text { - Finished } \\
\text { product } \\
\text { suppliers. }\end{array}$} & & & $\begin{array}{l}\text { - Boxes weighing less } \\
\text { than } 12 \mathrm{~kg}\end{array}$ & \\
\hline & & & $\begin{array}{l}\text { - Reduction of corrugated } \\
\text { expense. } \\
\text { - Reduction of transport } \\
\text { freight. } \\
\text { - Storage optimization. }\end{array}$ & \\
\hline
\end{tabular}

The data collection and SC flow calculation allowed establishing the quantity of boxes that flows within the SC, as an improvement strategy is established the initial operational flow which is existing before the project implemention, as it is shown in Fig.3.

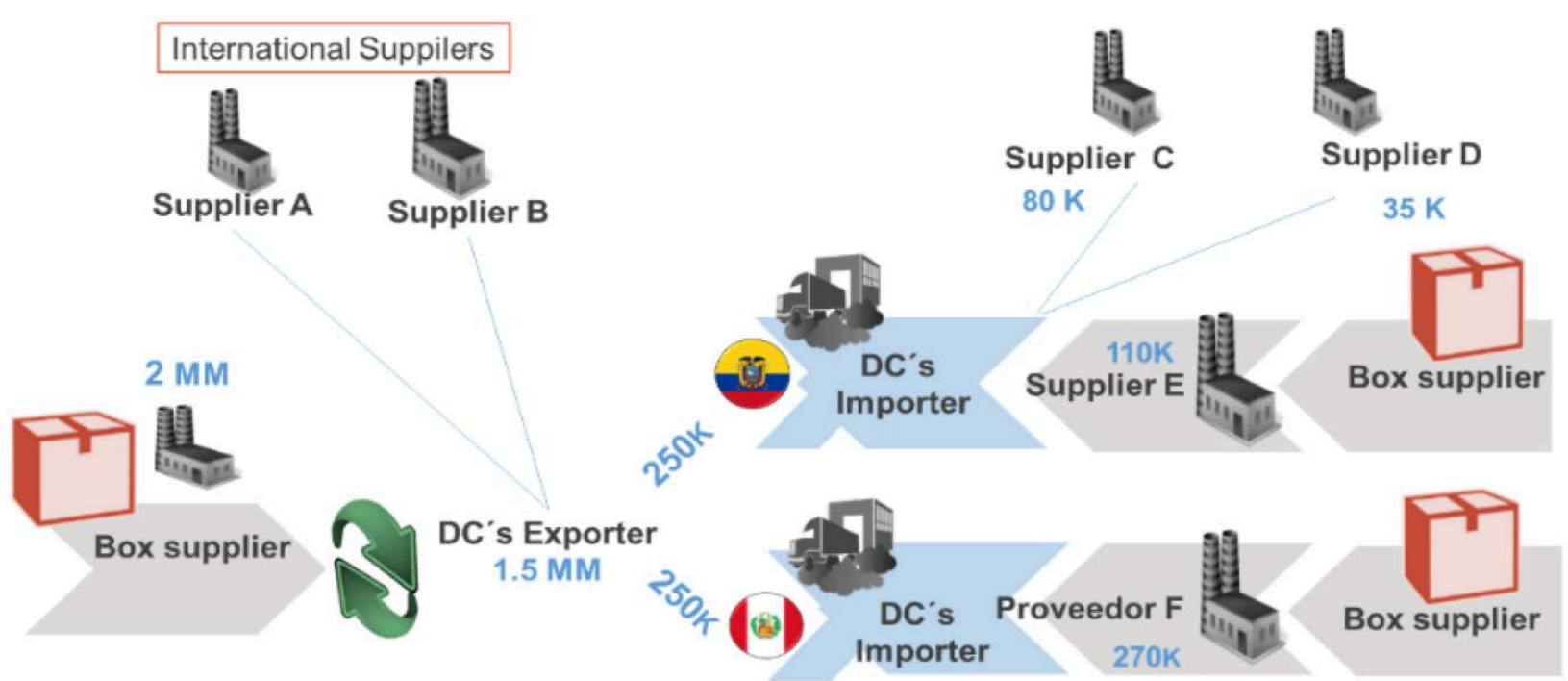

Fig. 3. Initial operating flow 


\section{Analysis of information}

Once the information concerning of the SKU's of the company was obtained, a Paretto analysis was carried out regarding common-characteristics references (SKU), so that either is possible to standardize several SKUs in a common-size single box or standardize a box that can be used in most of the stores. It means it can be used in primary storage and can also be reused to pack the products manufactured in the manufacturing centers or poll manufacturing plants as well as in the distribution of mentioned products to the customers.

Furthermore, the mentioned common-size box can be used in the supply, so it can be used either for suppliers of own plants or for materials manufacturers; therefore, guaranteeing the inclusion of all the SC links, as shown in Fig. 4.

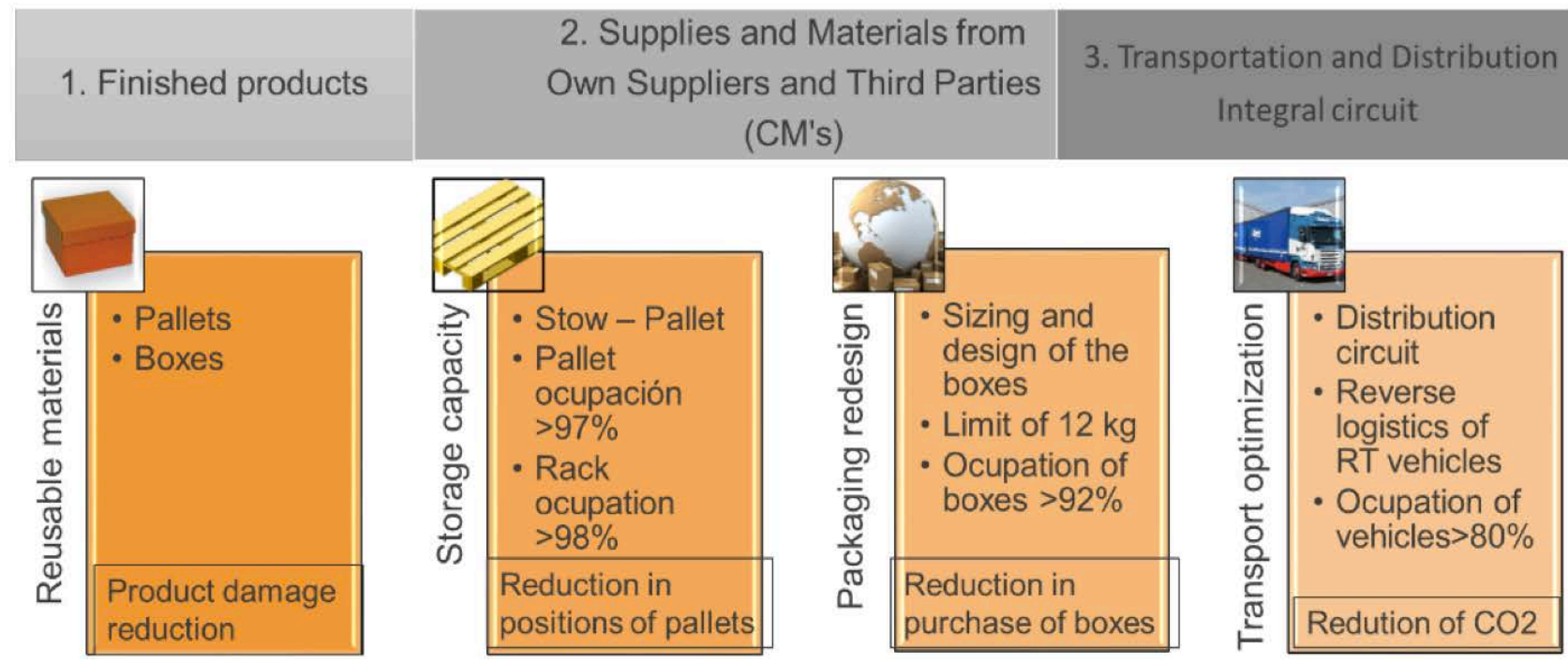

Fig. 4. Identification of opportunities for reuse of packaging in the supply chain (SC)

Another analytical tool used to determine the reasons for incurring high packing costs was the Cause-Effect diagram or Ishikawa diagram[12], which allowed to identify the root causes in the management of the company's packaging, as shown in Fig. 5.

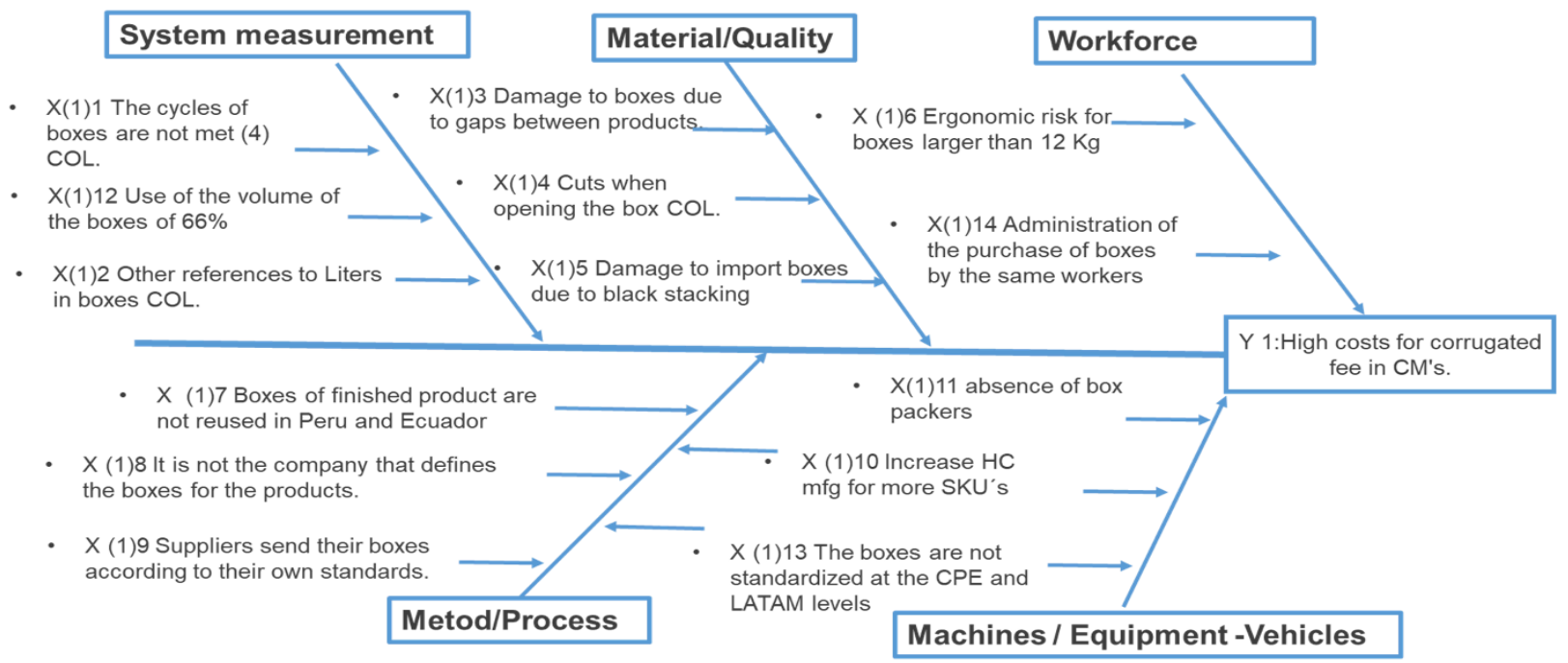

Fig. 5. Cause effect diagram to determine the reasons for high packing costs 


\subsection{Proposed execution model}

The input and output operating volumes in the year 2017 were taken as information data, and a set of operations was analyzed in Colombia, Peru and Ecuador (CPE cluster). Additionally, an analysis, testing of the current boxes was required as well as a measurement of the occupation in the pallets and warehouse in order to determine densities and optimal designs of the boxes finally.

To have a successful implementation of the project, the standards recommended by the PMBOK guide were followed [13]. For the adequate management of projects, a multidisciplinary work team was also available that involved several collaborators of the CPE cluster.

By means of the project implementation and through the participation of all project members, the company's SC flows could be redesigned, so that the strategic inclusion of a regional plant responsible for supplying the DC's located in Colombia and in Ecuador. It was also possible to establish that said regional plant is in charge of working directly with a specialized supplier of standardized boxes upstream of the SC; therefore, at the level the mentioned standardized boxes can be reused, as shown in Fig. 6.
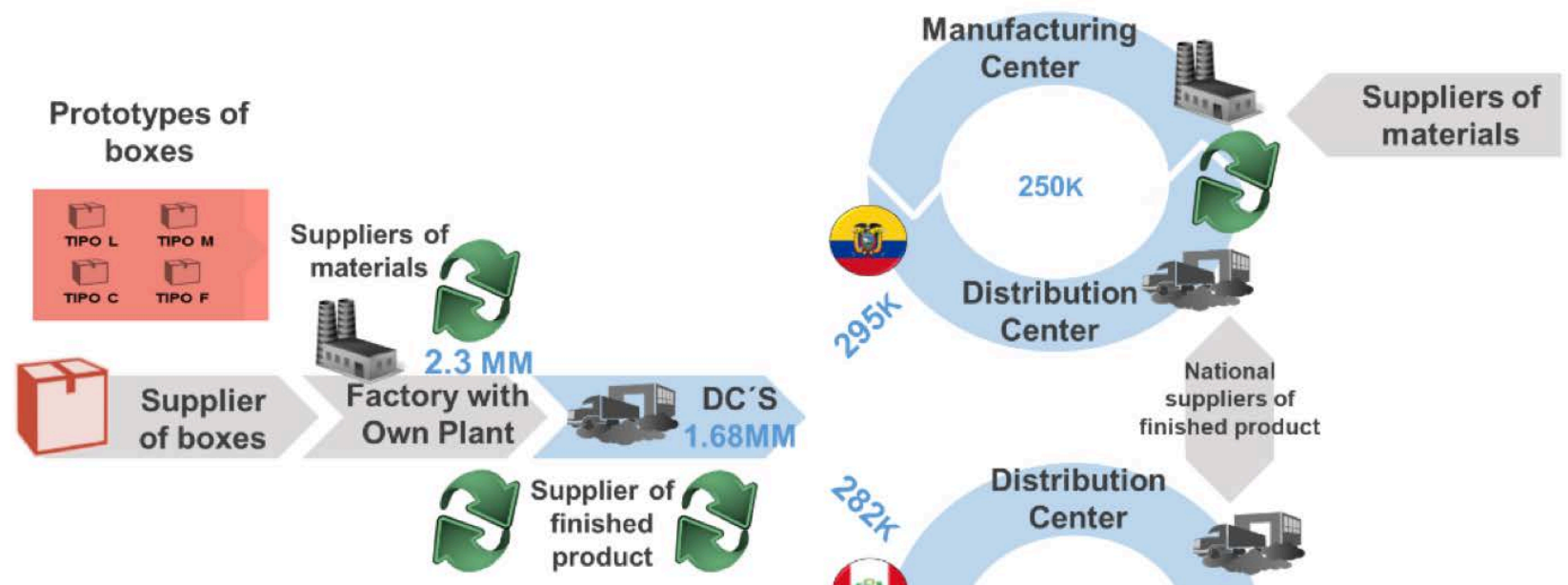

\section{Environmental impact caused by the use of boxes}

One of the main contributions of the reverse logistics studies is the analysis of the use of packaging; the aim was to reuse the boxes used as packaging for the products, otherwise they would be deposited in the environment, causing a negative environmental impact. 


\section{Design of new re-usable boxes in the SC}

Once the dimensions of the standardized boxes were determined to be used in the studied company SC, then a suitable design stage must be passed by means of a Computer Aided Design (CAD) software TOP [14]. The use of higher quality materials, and the execution of quality tests on the boxes are additional key approaches in order to maximize the life cycle of a box with standardized measures.

The study company considers that the box must fulfill the function of protecting the integrity of the product from the company to the client; however, it is not compulsory that the box must be used only once, it must be reused as many times as its design he allows it. To this end, technologies were also implemented to protect the integrity of the boxes, such as the use of elastic bands on DC's, the correct handling and classification of boxes by type. As shown in Fig. 7.

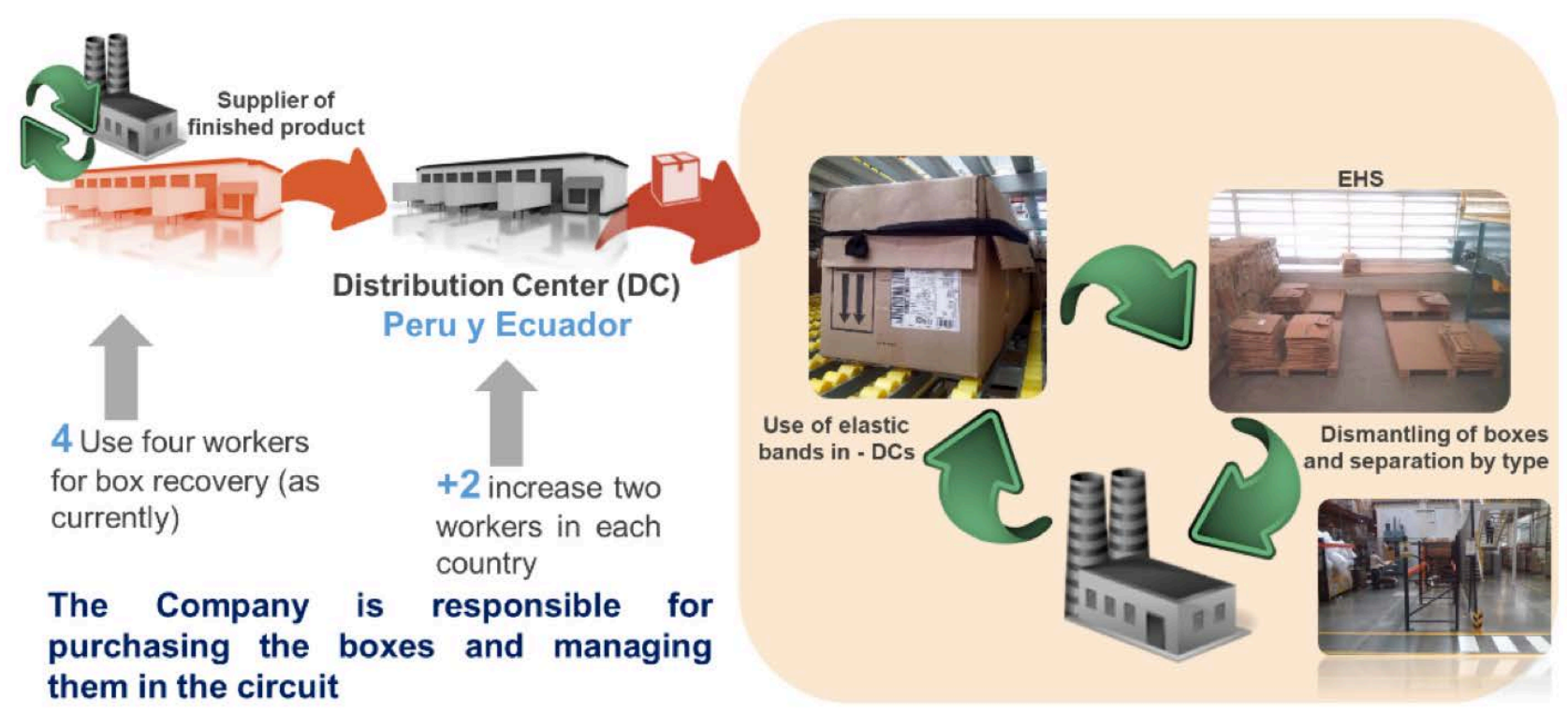

Fig. 7. Strategies for the re-use of boxes

\subsection{Control of project execution}

In order to perform a proper monitoring and control of the project execution, the Lean Six Sigma methodology was used as well as the Project charter recommended by the PM-BOK was also used. Undoubtedly, all of them increased the organizational level and the control of the activities that were carried out. As shown in Fig. 8. 


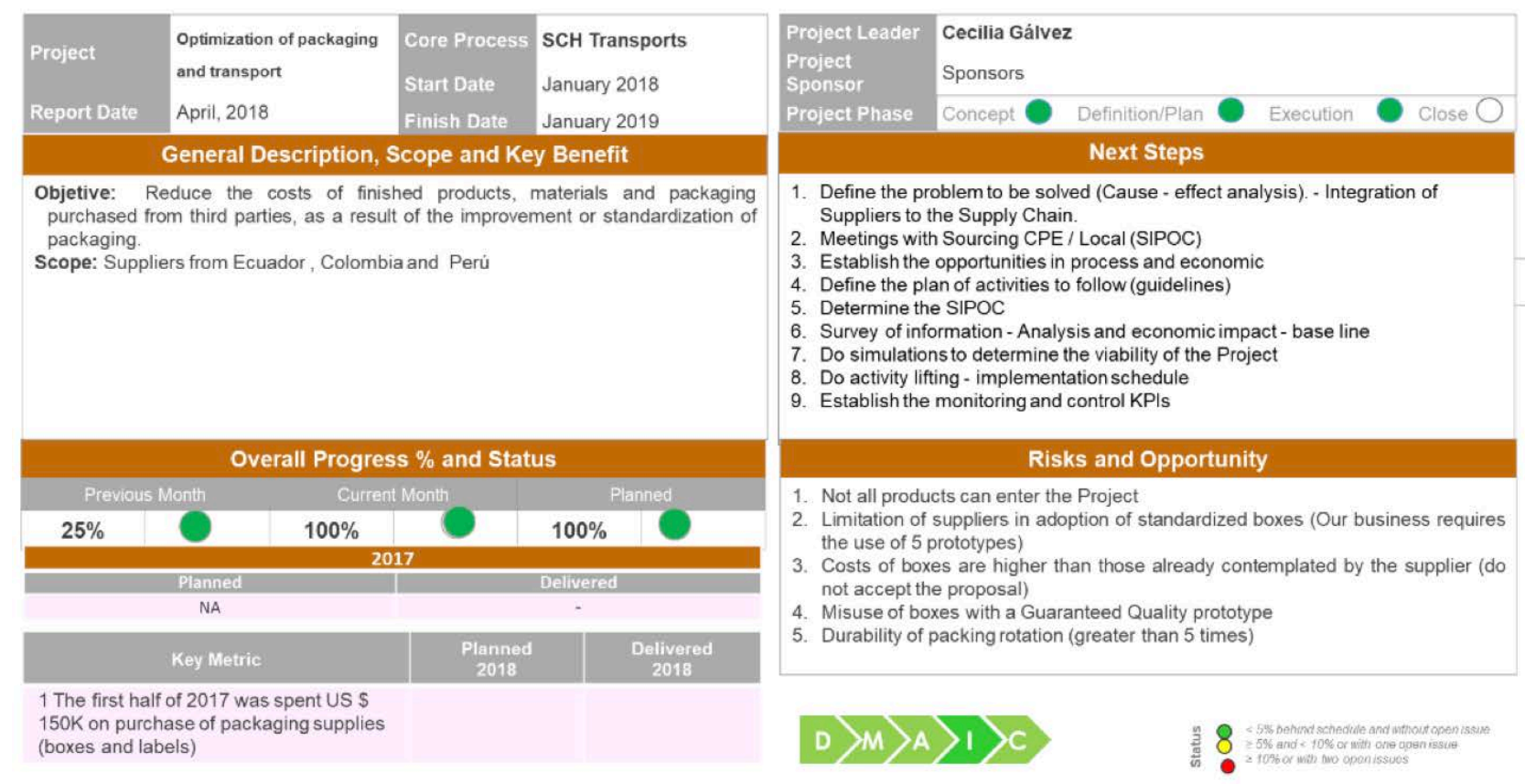

Fig. 8. Project Charter

\section{Results and Discussion}

Through the execution of the project it was possible to redesign the operational flow in the SC of the studied company, upgrading the SC work with fewer quantity of box suppliers and mainly reusing these in the SC which is a strategic strength in the organization.

By means of the packaging standardization used in the SC for the CPE cluster, a significant growth in the productivity cause the use of the wrapping and shipping materials was obtained, going from $66 \%$ to $92 \%$. An increase in the utilization of pallets in which the boxes of products are stacked from $76 \%$ to $97 \%$.

However, the main benefit and contribution as part of the Social and Global Responsibility is the reduction of $45 \%$ in the use of cardboard boxes generating less environmental pollution and the consequent decrease of approximately 100 tons of wood from trees that is required for the production of boxes and pallets

In addition, with the execution of the OTB project, there were notable increments in vehicle occupancy and reduction of freight fees that positively influences the operating costs of the company's logistics operations, as shown in Table 2 
Table 2. Indicators of packaging management

\begin{tabular}{llll}
\hline Indicator & Initially & Implementing OTB & Difference \\
\hline $\begin{array}{l}\text { Quantity of pallets - supplier of } \\
\text { finished product }\end{array}$ & 65.554 & 68.136 & $+4 \%$ \\
Amount of boxes & $3,5 \mathrm{MM}$ & $3,8 \mathrm{MM}$ & $+9,6 \%$ \\
Variety of boxes in Colombia & 4 & 10 & $+150 \%$ \\
Variety of boxes in CPE & 12 & 10 & $-16,66 \%$ \\
Platform height & $1,35 \mathrm{~m}$ & $1,45 \mathrm{~m}$ & $+7,04 \%$ \\
Occupation of the boxes & $66 \%$ & $92 \%$ & $+26 \%$ \\
Pallet occupation & $85 \%$ & $97 \%$ & $+12 \%$ \\
Vehicle occupancy & $42 \%$ & $80 \%$ & $+38 \%$ \\
Weight of the box (AVG) & $12,1 \mathrm{Kg}$ & $9,9 \mathrm{Kg}$ & $-18,8 \%$ \\
Weight of the platform (AVG) & $690 \mathrm{Kg}$ & $676 \mathrm{Kg}$ & $-2,02 \%$ \\
Units/box (AVG) & 41 & 33 & $-19,5 \%$ \\
Freights (Factory- DC's) & 8 & 5 & $-37,5 \%$ \\
Freights (Peru/Ecuador-cm) & 3 Ecuador & 2 Ecuador & $-37,5 \%$ \\
& 5 Perú & 3 Perú & \\
\hline
\end{tabular}

By means of financial impact calculation in the implementation of the OTB project through an analysis of sales, general and administrative expenses (SG \& A) for 2017, an effective reduction of $4 \%$ of the total costs of the SC in the CPE cluster could be determined; particularly, in Ecuador, savings are 3\%. As shown in Table 3.

Table 3. Calculation of the financial impact

\begin{tabular}{|c|c|c|c|c|c|c|c|}
\hline \multirow{2}{*}{$\begin{array}{l}\text { Consolidation } \\
\text { Concept }\end{array}$} & \multirow{2}{*}{$\begin{array}{l}\text { SC area } \\
\text { Picking } \\
\text { \&Logistic }\end{array}$} & \multicolumn{4}{|c|}{ (Fav) / Unfav. In USD MM } & \multirow[b]{2}{*}{ FY } & \multirow[b]{2}{*}{ YR 2} \\
\hline & & Q1 & Q2 & Q3 & Q4 & & \\
\hline $\begin{array}{l}\text { Corrugate Cost CM's } \\
\text { Fee PPV }\end{array}$ & Packaging & $-0,14$ & $-0,14$ & $-0,14$ & $-0,14$ & $-0,58$ & $-0,58$ \\
\hline $\begin{array}{l}\text { Freight Cost enterprise } \\
\text { CM's to Branch }^{\prime}\end{array}$ & Transportation & $-0,03$ & $-0,03$ & $-0,03$ & $-0,03$ & $-0,14$ & $-0,14$ \\
\hline Corrugate Cost & Packaging & 0,19 & 0,04 & 0,04 & 0,04 & 0,29 & 0,12 \\
\hline Freight Cost Corrugate & Transportation & 0,01 & 0,01 & 0,01 & 0,01 & 0,04 & 0,04 \\
\hline $\begin{array}{l}\text { Adittional resource for } \\
\text { box reuse }\end{array}$ & Packaging & 0,02 & 0,01 & 0,01 & 0,01 & 0,06 & 0,06 \\
\hline Total Benefit & & 0,03 & $-0,12$ & $-0,12$ & $-0,12$ & $-0,33$ & $-0,50$ \\
\hline $\begin{array}{l}\text { Reracking positions } \\
\text { 3PL optimization }\end{array}$ & Warehouse & $-0,01$ & $-0,008$ & $-0,008$ & $-0,008$ & $-0,043$ & $-0,043$ \\
\hline $\begin{array}{l}\text { Reracking Branch } \\
\text { CPE }\end{array}$ & Warehouse & 0,01 & 0,00 & 0,00 & 0,00 & 0,018 & 0,018 \\
\hline $\begin{array}{l}\text { Resources for reuse } \\
\text { process }\end{array}$ & Maintenance & 0,008 & 0,00 & 0,00 & 0,00 & 0,008 & 0,008 \\
\hline \multicolumn{2}{|l|}{ Total SG\&A } & $\mathbf{0 , 0 0}$ & $-0,01$ & $-0,01$ & $-0,01$ & $-0,023$ & $-0,018$ \\
\hline \multicolumn{2}{|c|}{ Total Saving (-)/Over cost(+) } & $\mathbf{0 , 0 2 9}$ & $-0,126$ & $-0,127$ & $-\mathbf{0 , 1 2 8}$ & $-0,348$ & $-0,514$ \\
\hline \multicolumn{2}{|l|}{ Total Cost Avoidance } & $\mathbf{0 , 0 3}$ & $-0,13$ & $-0,13$ & $-0,13$ & $-0,071$ & $-0,071$ \\
\hline
\end{tabular}




\section{Conclusions}

This project is appropriate to be applied in any business model and product type, it is sufficient to make a deep observation of the existing opportunities according to the market in which the reverse logistics is executed.

Having a good information system with highly reliable data and the last year of operation, especially of input and output of products, volumes of purchases of packaging and packaging materials as well as transport and distribution costs, and indicators of financial costs and expenses are keys to a robust decision making.

It must enclose a good management system by processes of the company, mainly in the area of operations, always keeping in mind the particularities of the business, regulatory and standardized procedure aspects as well as the application of total ethics to ensure the sustainability of the results in time.

For the implementation of this type of projects, one must have an open mind and a total predisposition to face new changes and challenges in business operations. Ideally the information should be raised by reliable information systems and integrated software such as JDE, SAP, etc.

The implementation of this project was possible with the use of project management methodologies PMBOK, Lean Six Sigma and OTB; however, it is essential that initially all company processes are clearly defined and updated for all company employees, that is, all those involved must know the business to their suppliers, the regulations and tax and legal regulations. In addition, the project must be aligned with the institutions' policies and values.

Finally, regarding the scientific contribution of this work, we can mention the establishment of a sequential methodology to implement a project to optimize the use of packaging in line with new environmental policies that minimize the emissions of waste in companies. This model in question can be implemented in multinational and regional companies thus contributing to the sustainability of the supply chain companies. Indeed, the model is presented for the proper management of packaging in multinational or regional companies that combines other traditionally used methodologies such as PMBOK, Six-Sigma and OTB.

\section{References}

1. Dekker, R., Fleischmann, M., Inderfurth, K., Van Wassenhove, L.N.: Quantitative Models for Reverse Logistics Decision Making. In: Reverse Logistics (2004)

2. Bowersox, D.J., Closs, D.J., Cooper, M.B.: Administration and logistics in the supply chain. McGrawHill, (2007)

3. Elmas, G., Erdoğmuş, F.: The importance of reverse logistics. Int. J. Bus. Manag. Stud. 3, 161-171 (2011)

4. Closs, D.J., Savitskie, K.: Internal and external logistics information technology integration. Int. J. Logist. Manag. 14, 63-76 (2003)

5. Armijos, M.: Strategic Planning Manual., Brasilia (2011) 
6. Rodrigues, R.: Metodología "Out of the Box" para la optimización de la cadena de suministro. Caso Avon - Zonalogística, https://www.zonalogistica.com/metodologia-out-of-the-box-para-laoptimizacion-de-la-cadena-de-suministro-caso-avon/

7. Geral, E.M.: ACORDO SETORIAL. http://file.abiplast.org.br/download/links/pnrs_e_o_acordo_ setorial_de_embalagens.pdf, Brasil (2017)

8. ABAD: National Plan of Solid Residues, https://newtrade.com.br/logistica/abad-promovepalestra-gratuita-sobre-o-plano-nacional-de-residuos-solidos/

9. Larson, E.W., Gray, C.F.: A Guide to the Project Management Body of Knowledge: PMBOK ( $\left.{ }^{\circledR}\right)$ Guide. Presented at the (2015)

10. CHEN, M., DAl, J.: MaxLoad Pro: Cargo Load Configuration Software [J]. Packag. Eng. 6, 85 (2004)

11. WANG, Y., KONG, F., LIU, M., WEN, R., JI, H.: Research on Application of TOPS Pro Software in Optimum Packaging Design for Liquid Milk [J]. Packag. Eng. 10, 58 (2008)

12. Ivanov, D., Tsipoulanidis, A., Schönberger, J.: Global Supply Chain and Operations Management. Springer Berlin Heidelberg, Berlin (2017)

13. Rose, K.H., Indelicato, G.: Book Review: A Guide to the Project Management Body of Knowledge (PMBOK ${ }^{\circledast}$ Guide), Fourth Edition. Proj. Manag. J. 40, 104-104 (2009). doi:10.1002/pmj.20125

14. TOPS Software Corporation: TOPS Pro and MaxLoad Pro software for package design, pallet optimization and load optimization planning., http://www.topseng.com/ 